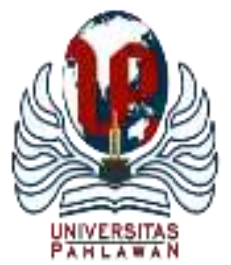

Edukatif : Jurnal Ilmu Pendidikan Volume 3 Nomor 6 Tahun 2021 Halm 4245 - 4253

EDUKATIF: JURNAL ILMU PENDIDIKAN

Research \& Learning in Education

https://edukatif.org/index.php/edukatif/index

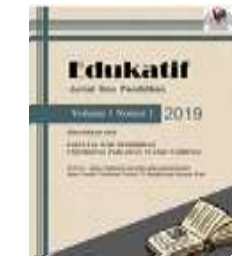

\title{
Kepemimpinan Inovatif dalam Penyelenggaraan Pendidikan di Masa Pandemi Covid-19
}

\author{
Suyitno ${ }^{\bowtie}$ \\ STIE Indonesia Malang, Indonesia

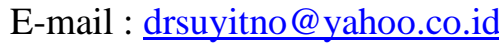

\begin{abstract}
Abstrak
Penelitian ini bertujuan untuk mengetahui model kepemimpinan inovatif kepala sekolah dalam melaksanakan pengelolaan sekolah yang mengalami perubahan besar sebagai dampak pandemi Covid-19 saat ini. Metode penelitian yang digunakan adalah metode kualitatif deskriptif dan data dianalisis secara interaktif. Hasil penelitian ini menunjukkan bahwa Pertama, inovasi yang dilakukan oleh Kepala Sekola antara lain untuk menjawab dan mengurai tiga tantangan yakni kurikulum apa yang akan digunakan, menyusun strategi pembelajaran, dan pemanfaatan teknologi informasi. Kedua, inovasi kepala sekolah dengan mengembangkan komunikasi dan jaringan kerjasama untuk saling mendukung satu sama lain untuk membentuk produktivitas dan merumuskan solusi terbaik dalam menyelesaikan persoalan-persoalan esensial organisasi sekolah. Ketiga, inovasi kepala sekolah melalui kepemimpinan yang adaptif teknologi dalam mendukung akselerasi merdeka belajar untuk mewujudkan visi dan tujuan yang baik. Inovasi kepala sekolah ditengah kondisi ketidakpastian menuntut untuk mampu beradaptasi dengan cepat terhadap situasi yang berubah dengan cepat yang berorientasi pada mutu dan efektifitas operasional sekolah.
\end{abstract}

Kata Kunci: kepemimpinan inovatif, sekolah, pandemi covid-19

\begin{abstract}
This study aims to determine the principal's innovative leadership model in implementing school management which has undergone major changes as a result of the current Covid-19 pandemic. The research method used is descriptive qualitative method and the data were analyzed interactively. The results of this study indicate that First, the innovations made by the Principal are to answer and unravel three challenges, namely what curriculum to use, developing learning strategies, and the use of information technology. Second, the principal's innovation by developing communication and cooperation networks to support each other to form productivity and formulate the best solutions in solving essential problems of school organization. Third, principal innovation through technology-adaptive leadership in supporting the acceleration of independent learning to realize good visions and goals. Principal innovation in the midst of uncertainty demands to be able to adapt quickly to rapidly changing situations that are oriented towards the quality and effectiveness of school operations.
\end{abstract}

Keywords: innovative leadership, school, covid-19 pandemic.

Copyright (c) 2021 Suyitno

$\triangle$ Corresponding author:

Email : drsuyitno@yahoo.co.id

DOI : https://doi.org/10.31004/edukatif.v3i6.1432 


\section{PENDAHULUAN}

Kepemimpinan inovatif menjadi tuntutan dalam pengelolaan pendidikan dewasa ini, apalagi dengan munculnya pandemi covid-19 akhir-akhir ini yang memaksa tatanan kehidupan masyarakat untuk keluar dari zona nyaman. Pandemi virus korona yang sedang berlangsung telah menciptakan krisis yang belum pernah terjadi sebelumnya dengan konsekuensi global. Pandemi Covid 19 yang telah merebak sejak awal tahun 2020 dan telah berdampak signifikan pada semua aspek kehidupan yang ada, tak terkecuali dunia pendidikan. Dinamika yang muncul, di satu sisi kualitas kuantitas pendidikan tetap harus terjamin dalam jangka waktu yang panjang dan disisi lain kesehatan tetap harus terjaga (Kruse et al., 2020). Sebagai upaya yang dilakukan untuk pemenuhan layanan kebutuhan pendidikan kepada peserta didik di masa pandemi corona covid-19 maka pemerintah mengeluarkan regulasi tentang penyelenggaraan belajar dari rumah melalui Surat Keputusan Bersama Menteri Pendidikan Dan Kebudayaan, Menteri Agama, Menteri Kesehatan, Dan Menteri Dalam Negeri Republik Indonesia Nomor 03/ KB/ 2021 Nomor 384 Tahun 2021, Nomor HK.01.08/ MENKES/ 4242/ 2021, Nomor 440-717 TAHUN 2021 (SKB 4 MENTERI Panduan Pembelajaran Tatap Muka. 2021.). Berdasarkan regulasi pemerintah tersebut, penyelenggara pendidikan diberikan kebebasan dalam mengelola kegiatan belajar mengajar melalui pembelajaran tatap muka terbatas dengan tetap menerapkan protokol kesehatan; dan/atau pembelajaran jarak jauh.

Kondisi tidak nyaman yang sedang dihadapi masyarakat saat ini menimbulkan dampak positif bagi penyelenggaraan pendidikan yakni dapat memotivasi sekolah untuk menjadi lebih baik di masa depan (Gualano et al., 2020); (Strielkowski \& Wang, 2020). Berdasarkan penelitian yang dilakukan oleh (D'angelo et al., 2021); (Fernandez \& Shaw, 2020) dan (Kurita et al., 2021) terdapat tiga praktik terbaik kepemimpinan untuk menavigasi tantangan adaptif yang tidak terduga seperti yang ditimbulkan oleh pandemi corona virus. Pertama, dengan menerapkan jenis kepemimpinan pelayan (servant leadership), yang menekankan pemberdayaan, keterlibatan, dan kolaborasi, para pemimpin akademik dengan kecerdasan emosional dan stabilitas emosional harus menempatkan kepentingan orang lain di atas kepentingan mereka sendiri. Kedua, para pemimpin akademik harus mendistribusikan tanggung jawab kepemimpinan ke jaringan tim di seluruh organisasi untuk meningkatkan kualitas keputusan yang dibuat dalam penyelesaian krisis. Ketiga, para pemimpin harus berkomunikasi dengan jelas dan sering kepada semua pemangku kepentingan melalui berbagai saluran komunikasi.

Kunci keberhasilan suatu sekolah pada hakikatnya terletak pada efisiensi dan efektivitas dari kepala sekolah, karena suksesnya suatu sekolah adalah merupakan keberhasilan kepala sekolah itu sendiri, salah satu kriteria keberhasilan sekolah diperlukan adanya kepemimpinan kepala sekolah yang berkualitas. Perlunya kualitas kepemimpinan kepala sekolah, maka selalu ditekankan pentingnya tiga kemampuan dasar yang perlu dimiliki oleh kepala, sekolah, yaitu conceptual skills, human skills dan technical skills (Chandra et al., 2019).

Peran kepala sekolah pada era desentralisasi saat ini sudah seharusnya melakukan berbagai tindakan yang bersifat inisiatif dalam memimpin dan mengelola saatuan pendidikan yang ia pimpin. Hal ini tidak lepas dari manajemen kepemimpinan kepala sekolah yang berjiwa inovatif. Pada era new normal ini sekolah membutuhkan proses pembelajaran yang dapat menjadikan anak dalam situasi dan kondisi proses pembelajaran yang aman dan kuat imun dan iman dalam menyikapi proses pembelajaran merdeka belajar (Djafri et al., 2020). Peran strategis kepala sekolah sebagai sebuah jabatan yang dapat mengembangkan dan mengarahkan satuan pendidikan yang dikelolanya kearah keberhasilan. Kepimpinan kepala sekolah dalam hal ini harus benar-benar bersifat instruktif atau inovatif dan kreatif serta profesional, mengingat pengalaman selama ini peran kepala sekolah hanya bersifat instruktif (top down). Hal tersebut tentunya tidak baik bagi keberlangsungan sebuah intitusi pendidikan di era industrialisasi 4.0 seperti saat sekarang ini.

Dalam menghadapi kondisi seperti saat ini dunia pendidikan dengan berbagai kebijakan yang telah digulirkan pemerintah pusat maupun daerah, melakukan segala upaya agar pelayanan pada satuan pendidikan tetap dapat berjalan dengan menyesuaikannya situasi krisis. Maka, dari itu peran kepala sekolah sebagai 
pemimpin di satuan pendidikan yang ada dituntut untuk melakukan berbagai inovasi dengan berbagai penyesuaian sesuai dengan kebutuhan yang ada dan segala perencanaan yang matang. Kepala sekolah inovatif harus dapat membangun inovasi itu penuh dengan resiko kegagalan dan kerugian, serta dapat mengatasi kompleksitas masalah yang harus dihadapi dengan kesabaran dan keberanian dalam mengambil keputusan. Itulah kenapa bahwa kepemimpinan menjadi salah satu bagian terpenting dari lahirnya produk atau layanan yang inovatif (Candra et al., 2020). Kepemimpinan inovatif sesuai untuk administrator sekolah di masyarakat saat ini. Beberapa kajian yang menyebutkan ciri kepemimpinan inovatif antara lain (Owen et al., 2015), (Marron \& Cunniff, 2014), (Othman \& Rahman, 2013), (Metcalf \& Morelli, 2015), (Maladzhi et al., 2012), dan (Johannessen \& Skaalsvik, 2014) ditemukan 35 elemen utama dari kerangka teoritis. Hal ini menunjukkan adanya ragam sikap terhadap elemen yang menjadi ciri kepemimpinan inovatif. Secara garis besar bahwa ada empat elemen yang digunakan untuk mengukur kepemimpinan inovatif dalam penelitian ini diantaranya visioner, kolaborasi, pengambilan risiko, dan perubahan berorientasi (Somsueb et al., 2019). Pengendalian keadaan seperti saat ini harus dilakukan kepala sekolah agar pelayanan pendidikan tetap berjalan dengan baik dengan menjunjung tinggi keselamatan dan Kesehatan warga sekolah. Pengelolaan pembelajaran di masa pandemi covid-19 saat ini, sangat membutuhkan peran kepala sekolah yang inovatif dengan menyusun berbagai perencanaan untuk menunjang proses pembelajaran bagi peserta didik dan kesiapan pendidik dalam melaksanakan pembelajaran di masa pandemi covid-19. Tidak dapat dipungkiri covid-19 membawa dampak perubahan yang sangat signifikan bagi proses pembelajaran yang dilaksanakan di sekolah. Untuk tetap terlaksananya proses pembelajaran di masa pandemi covid-19 ini, berbagai konsep dan pendekatan pembelajaran ditawarkan sebagai sebuah solusi.

Kondisi krisis yang melanda saat ini yang disebabkan oleh pandemi covid-19,memberikan pengalaman baru bagi dunia pendidikan untuk dapat melakukan berbagai penyesuaian yang menuntut peran dari kepala sekolah untuk melakukan inovasi dan kreatifitas dalam mengorganisasi pembelajaran. Beberapa hasil penelitian membuktikan bahwa pengelolaan pendidikan termasuk didalamnya aktivitas pembelajaran di lembaga pendidikan selama masa pandemi covid-19 mengalami permasalahan dan berujung pada ketidakefektifan pelaksanaan pendidikan (Setiani, 2020; Spyropoulou \& Koutroukis, 2021; Nadeak \& Juwita, 2020; Dewi \& Sadjiarto, 2021). Kepala Sekolah dituntut kreatif dan menjadi motivator yang baik untuk merancang kurikulum dan pembelajaran yang sesuai dengan kondisi darurat bencana covid-19 ini melalui optimalisasi serta tata kelola sekolah melalui pengorganisasi bagi semua pihak sekolah sehingga proses pembelajaran di sekolah dapat tetap terlaksana dengan baik. Berdasarkan hasil observasi dari studi pendahuluan, tata kelola yang dilaksanakan di SMA Al Hikmah Malang menunjukkan efektivitas dan keberhasilan yang cukup baik walaupun dalam situasi dan kondisi new normal akibat pandemi covid-19 saat ini. Oleh sebab itu, penelitian ini bertujuan mendiskripsikan dan menganalisa kepemimpinan inovatif dalam pengelolaan pendidikan dalam situasi pandemi covid-19 di SMA Al Hikmah Malang.

\section{METODE PENELITIAN}

Penelitian ini menggunakan desain penelitian kualitatif dengan jenis studi kasus. Lokasi penelitian di SMA Al Hikmah Malang diambil dengan kriteria keunikan dan keberhasilan dalam pengelolaan pendidikan di masa pandemi Covid-19. Dalam penelitian ini menggunakan purposive sampling dan didukung dengan snowball sampling sehingga kehadiran peneliti merupakan keniscayaan untuk proses pengumpulan data melalui wawancara, observasi, dan dokumentasi. Wawancara dilakukan dengan menggunakan indepht interviw kepada informan sebanyak 15 orang antara lain kepala sekolah sebagai key informan, 3 orang wakil kepala sekolah, 5 orang guru, 3 orang staf Tata Usaha, 3 orang wali murid. Observasi dilakukan dengan observasi partisipatif terutama pada observasi terfokus setelah observasi deskriptif dan selektif. Untuk melengkapi analisis, dibuat ringkasan kontak dokumen yang diperoleh dari catatan lapangan dan ringkasan kontak observasi. Selama pengumpulan data transkrip, pengkodean, dan meringkas kontak wawancara dikelola. Reduksi data dilakukan dengan tujuan memperhatikan fokus penelitian. Data dianalisis dengan 
menggunakan model analisis interaktif seperti yang disarankan Miles dan Huberman (dalam (Suyitno, 2018). Untuk memastikan validitas dan reliabilitas pemeriksaan data kredibilitas, konfirmabilitas, kebergantungan, dan transferabilitas diambil. Pemeriksaan kredibilitas dilakukan dengan menggunakan triangulasi sumber dan teknik serta pemeriksaan informan. Ketergantungan dan kepastian data diperiksa dengan menggunakan audit proses. Untuk memastikan transferbilitas, kajian ini keotentikan data dibuat sistematis dan memiliki kemampuan dipahami oleh semua pihak serta kegiatan penelitian ini dilakukan selama 4 (empat bulan).

\section{HASIL DAN PEMBAHASAN PENELITIAN}

Dalam masa krisis sebagai akibat pandemi Covid 19, daya inovatif pemimpin sekolah menjadi tuntutan utama. Kepala sekolah harus terlibat dalam komunikasi yang efektif, memfasilitasi pemahaman dalam kondisi ketidakpastian, fleksibel dan adaptif, dan memperhatikan kesejahteraan emosional dan kesehatan warga sekolah. Pendidik berada di tengah-tengah salah satu masa yang paling menantang dan luar biasa dalam sejarah profesi. Karena kondisi pandemi yang selalu berubah, guru dan sekolah terus dipaksa untuk beradaptasi untuk mendidik siswa dengan aman.

Beberapa inovasi yang dilakukan oleh Kepala Sekola SMA Al Hikmah Malang antara lain untuk menjawab dan mengurai tiga tantangan yakni kurikulum apa yang akan digunakan, menyusun strategi pembelajaran, dan pemanfaatan teknologi informasi. Kepala sekolah bersama guru-guru di SMA Al Hikmah Malang melakukan penyederhaan kurikulum dengan cara melakukan pemetaan kompetensi dengan mendekatkan area belajar yang sejenis. Kemudian harus mengevaluasi materi esensial pada Kurikulum 2013 dan keberadaan dan proporsi materi di setiap domain yang tetap diajarkan. Misalnya kurikulum Matematika SMA, terdapat beberapa materi berbeda, seperti materi persamaan linear, persamaan kuadrat dan fungsi Kuadrat. Materi berbeda ini dimaksudkan untuk mendukung kompetensi umum matematika. Guru dapat melakukan pengurangan materi, tetapi kompetensi umum harus dapat dicapai. Bila kompetensi umum matematika tersebut sudah dimililiki, maka murid akan mudah mempelajari secara mandiri kompetensi khusus yang berkaitan dengan materi matematika yang lain. Akan tetapi tetap perlu diberi catatan, terdapat beberapa materi kurikulum yang memang tidak bisa disederhanakan.

Pemilihan strategi pembelajaran yang akan digunakan oleh guru-guru di SMA Al Hikmah Malang, kepala sekolah memberikan keleluasaan dan dukungan terhadap inivasi dan kreativitas pada penggunaan media aplikasi on-line yang sekiranya tepat dan efektif diterapkan bagi guru dan murid. Beberapa media sebagai sarana dalam menyampaikan materi kepada murid seperti Whats App, Zoom meeting, googlemeet, Youtube, Google Classroom dan masih banyak lainnya sebagai pilihannya. Sebagai antisipasi kekurangsiapan para guru pada penggunaan aplikasi-aplikasi tersebut, Kepala Sekolah membekali para guru dengan mengadakan pelatihan pemanfaatan aplikasi sebagai media dalam menyampaikan pembelajaran dengan mengundang narasumber yang kompeten.

Pemanfaatan teknologi informasi saat ini menjadi suatu keniscayaan, apalagi pada proses pembelajaran di masa pandemi Covid-19 saat ini. Kepala Sekolah SMA Al Hikmah Malang mengawal sekaligus mengevaluasi proses pembelajaran yang dilakukan oleh para guru. Dengan mempertimbangkan kondisi obyektif, media on-line tidak sepenuhnya efektif digunakan terhadap seluruh proses pembelajaran, hal ini disebabkan dari beberapa hal diantaranya signal internet yang kurang mendukung. Sehingga proses pembelajaran harus didukung dengan pola pembelajaran luring, yakni membentuk kelompok-kelompok yang terdiri dari 5 sampai 10 siswa dan dilakukan dengan protokol kesehatan yang ketat. Demikian juga pada saat pelaksanaan ulangan tengah semester mata pelajaran, digunakan googleform atau terkadang juga guru harus melakukan kunjungan ke kelompok-kelompok yang sudah dibentuk. Dengan kemudahan dan kecanggihan media on-line yang tersedia dalam proses pembelajaran cukup membantu meskipun kurang efektif dibandingkan dengan pembelajaran tatap muka. Keinginan para guru SMA Al Hikmah Malang untuk memberikan terobosan yang lainnya pada sarana pembelajaran daring ini seperti pembuatan soal dengan 
aplikasi on-line menjadi terhambat karena faktor sarana yang terbatas dimiliki oleh anak sehingga hanya memberikan sarana pembelajaran daring melalui media terbatas yang mudah dapat diakses oleh siswa.

Ketiga upaya yang dilakukan oleh Kepala Sekolah tersebut diatas, merupakan inovasi dalam menjawab tiga tantangan dalam poses pendidikan di SMA Al Hikmah Malang yakni aspek kurikulum yang digunakan, strategi pembelajaran yang diterapkan dan pemanfaatan teknologi informasi dalam proses pembelajaran. Kepemimpan inovatif dapat mengelola dan mengambil keputusan untuk fase evaluasi, mulai pada tahap perencanaan, pengelolaan, pengembangan indikator menjadi program inti kepemimpinan yang inovatif dalam pembelajaran dengan memperhatikan adaptasi informasi teknologi yang responsif untuk implementasi dan aplikatif. Hal ini sejalan dengan penelitian yang dilakukan oleh Bagwell, (2020); Wilson et al. (2012) yang menyatakan bahwa pemimpin sekolah dituntut dapat mendemonstrasikan ketekunan dan pola pikir berkembang dengan memodelkan bagaimana bersikap positif dan secara produktif menanggapi kesulitan dan tantangan. Disisi lain Kaden, (2020); Harris \& Jones (2020) juga menyatakan para pemimpin sekolah dipaksa untuk memikirkan kembali sifat dan tingkat perubahan yang diperlukan untuk mendukung guru dan siswa dalam mengadopsi teknologi dan keterampilan teknis untuk menavigasi pengajaran dan pembelajaran secara lingkungan virtual.

Kemampuan kepala sekolah untuk berkomunikasi secara efektif, terutama dalam mengembangkan sekolah sebagai komunitas belajar dalam menyelesaikan persoalan-persoalan organisasi sekolah merupakan hal yang esensial. Di saat-saat seperti ini, kepala sekolah dituntut dapat menangkap kompleksitas pandemi virus corona, mengumpulkan informasi saat lebih banyak tersedia dan mengomunikasikan kompleksitas ini, mungkin dalam istilah yang lebih sederhana, kepada semua pemangku kepentingan sambil menguraikan potensi solusi yang masuk akal terutama dalam persoalan kelembagaan sekolah.

Dalam situasi dan kondisi yang serba tidak nyaman sebagai akibat wabah pandemi Covid-19, Kepala Sekolah SMA Al Hikmah Malang berupaya meningkatkan intensitas komunikasi baik kepada para guru, siswa, orang tua dan stakeholder lainnya. Tidak terbatas pada proses belajar mengajar semata yang menjadi tema dalam komunikasi, tetapi tentang kesehatan, kondisi keluarga, pemberian semangat sampai pada saransaran yang hendaknya dilakukan oleh sekolah sebagai komunitas belajar. Komunikasi yang dilakukan dengan para guru lebih menekankan pada pelaksanaan tugas mengajar dan tugas profesional lain yang melekat pada kewajiban guru. Kepala Sekolah mendorong kreativitas dan gagasan baru yang mendukung efektivitas pelaksanaan tugas pembelajaran online, yang hal ini dilakukan seminggu sekali dengan aplikasi zoom meeting. Pada kesempatan itu pula, kepala sekolah menyampaikan berbagai persoalan sekolah yang kemudian didiskusikan untuk mencari kesepakatan penyelesaiannya. Demikian pula komunikasi yang dilakukan kepala sekolah kepada wali murid, melalui perwakilan dari beberapa wali murid yang sudah mampu menggunakan aplikasi zoom meeting, secara periodik dilaksanakan rapat secara online untuk mensosialisasikan kebijakan sekolah serta mencari masukan-masukan yang konstruktif dari masyarakat dan wali murid bagi kemajuan sekolah SMA Al Hikmah Malang. Di saat-saat seperti ini, Kepala Sekolah berupaya menangkap kompleksitas pandemi virus corona, mengumpulkan informasi saat lebih banyak tersedia dan mengomunikasikan kompleksitas ini, mungkin dalam istilah yang lebih sederhana, kepada semua pemangku kepentingan sambil menguraikan potensi solusi yang masuk akal. Komunikasi seperti ini lebih sering dilakukan oleh kepala sekolah pada masa-masa pandemi Covid-19 dibandingkan pada masa normal dengan alasan situasi dan kondisi saat ini sangat tidak menentu sehingga memerlukan penyamaan persepsi dan kesatuan tindak bagi kelangsungan dan efektivitas proses belajar mengajar di SMA Al Hikmah Malang. Integritas dan kredibilitas pemimpin penting dalam krisis; jika pemimpinnya tidak kredibel maka pesan yang dikomunikasikan tidak akan dianggap kredibel. Pemimpin akademik yang mampu mengomunikasikan visi bersama yang meyakinkan dan bijaksana untuk institusi yang realistis dan dapat dicapai setelah krisis mereda dapat menginspirasi semua komponen sekolah. Hal ini sejalan dengan penelitian Marron \& Cunniff (2014); Somsueb et al. (2019) yang menyatakan bahwa pemimpin inovatif adalah individu yang menginspirasi kepercayaan di antara rekan kerja mereka, mereka telah menjadi anggota tim yang efektif dan melayani dengan baik dalam peran kepemimpinan 
masa lalu sebagai kolaborator, dan mereka mengambil "langkah ekstra" untuk memastikan bahwa misi tim tercapai. McLeod \& Dulsky (2021), Kruse et al., (2020) menyatakan bahwa selama krisis, para pemimpin sekolah-seperti mereka rekan-rekan di lembaga lain-harus terlibat secara efektif komunikasi, memfasilitasi pengertian dalam kondisi ketidakpastian, fleksibel dan adaptif, serta memperhatikan kesejahteraan emosional dan kesehatan karyawan.

Kepala sekolah dituntut untuk lebih meningkatkan lagi kemampuannya dalam pengembangan sekolah sehingga sekolah dapat menghasilkan siswa yang berkualitas. Oleh karena saat ini masih dalam kondisi dan situasi yang tidak menentu sebagai akibat dari wabah virus Corona yang akhirnya juga sangat mempengaruhi pengelolaan lembaga pendidikan, maka dibutuhkan kepala sekolah yang adaptif teknologi dalam mendukung akselerasi merdeka belajar untuk mewujudkan visi dan tujuan yang baik. Ketidakpastian menuntut para pemimpin untuk beradaptasi dengan cepat terhadap situasi yang berubah dengan cepat, dan untuk memanfaatkan keterampilan dan jenis kepemimpinan yang berbeda. Kepala sekolah SMA Al Hikmah Malang merespon kondisi yang demikian dengan upaya untuk menghadapi segera, sambil tetap fokus pada masa depan, menciptakan lingkungan belajar dan mengajar yang terbaik, dan hasil bagi siswa. Konektivitas dan hubungan yang dibangun antar komponen sekolah dan mengoptimalkan interaktif baik secara formal maupun informal berupaya untuk menemukan solusi-solusi atas permasalahan yang dihadapi bersama di SMA AL Hikmah Malang. Bahkan dalam hal ini, Kepala Sekolah SMA Al Himah Malang membentuk satuan tugas (satgas) yang terkait mengelola informasi terkait pandemi Covid-19 baik internal maupun eksternal yang kemudian dipergunakan sebagai bahan pertimbangan kebijakan sekolah di SMA Al Hikmah Malang. Satuan tugas yang dibentuk dan dikendalikan oleh Kepala Sekolah SMA Al Hikmah Malang ini juga bertugas menangkal informasi-informasi yang tidak benar (hoax) dengan tujuan agar informasi yang diterima komponen sekolah termasuk masyarakat sekitar sekolah merupakan informasi yang benar dan memiliki derajad validitas yang tinggi. Hal ini sejalan dengan penelitian yang dilakukan oleh Sutama (2021), Suheny et al. (2020) dan Nugroho et al. (2021) yang menyatakan bahwa kepemimpinan adaptif sangat relevan dalam menghadapi krisis, karena dalam kepemimpinan adaptif melibatkan empat aspek yang penting yaitu (1) Antisipasi kebutuhan, tren, dan pilihan masa depan (2) Artikulasi, kebutuhan di masa mendatang untuk membangun pemahaman bersama dan dukungan untuk melaksanakan aksi. (3) Adaptasi mendorong pembelajaran berkelanjutan dan penyesuaian terhadap respon yang diperlukan (4) Akuntabilitas mencakup transparansi dalam proses pengambilan keputusan dan keterbukaan terhadap tantangan dan umpan balik. Selanjutnya Bagwell (2020) juga menyatakan bahwa dengan mengadopsi pendekatan adaptif untuk kepemimpinan, pemimpin sekolah dapat membangun ketahanan dan kapasitas untuk komunitas sekolah mereka dalam mengatasi gangguan di masa depan yang disebabkan oleh pandemi..

Berdasarkan hasil temuan penelitian diatas menunjukkan bahwa kepala SMA Al Hikmah Malang telah mampu melakukan beberapa inovasi tata kelola lembaga pendidikan pada masa pandemi covid-19 ini pada aspek pembelajaran dengan melakukan pengelolaan kurikulum, menyusun strategi pembelajaran, dan pemanfaatan teknologi informasi. Sedangkan pada aspek memperkuat iklim sekolah dengan melakukan peningkatan komunikasi serta berupaya dan jaringan kerjasama untuk menemukan solusi terhadap permasalahan-permasalah yang ada dan ditunjang dengan model kepemimpinan yang adaptif terhadap perkembangan teknlogi informasi. Beberapa inovasi kepala sekolah tersebut yang membuktikan efektivitas pengelolaan sekolah di SMA Al Hikmah Malang di masa pandemi covid-19 saat ini. Peneliti menghadapi beberapa keterbatasan yang dapat dipengaruhi dari kondisi penelitian yang dilakukan antara lain: 1) Penelitian ini hanya dilaksanakan pada satu situs (sekolah), jika dilaksanakan dengan lebih banyak situs memungkinkan untuk mendapatkan hasil penelitian yang lebih baik, 2) Subyektifitas yang ada pada peneliti dan periode pengamatan, penelitian ini sangat tergantung kepada interpretasi peneliti tentang makna yang tersirat dalam wawancara sehingga kecenderungan untuk bias masih tetap ada, 3). Periode penelitian yang hanya menggunakan 4 bulan pengamatan sehingga memungkinkan pengungkapan kurang dapat menggambarkan kondisi yang sebenarnya dan jika periode penelitian yang lebih panjang akan lebih baik karena dapat 
menggambarkan kondisi sesungguhnya. Namun demikian, hasil penelitian ini setidaknya dapat digunakan sebagai acuan bagi kepala sekolah untuk melakukan tata kelola sebuah lembaga pendidikan dengan mengimplmentasikan strategi dan inovasi pada situasi dan kondisi yang serba terbatas akibat pandemi covid19 atau keadaan lain yang serupa dimana tuntutan proses pendidikan harus tetap berjalan.

\section{KESIMPULAN}

Tanggung jawab kepala sekolah di masa covid-19 ini hanya ada satu yaitu menjamin kualitas belajar murid melalui pelaksanaan fungsi manajemen dan kepemimpinan. Pengelolaan kepala sekolah yang inovatif dengan menyusun berbagai perencanaan untuk menunjang proses pembelajaran bagi peserta didik dapat dilakukan dengan, pertama, inovasi yang dilakukan oleh Kepala Sekola antara lain untuk menjawab dan mengurai tiga tantangan yakni kurikulum apa yang akan digunakan, menyusun strategi pembelajaran, dan pemanfaatan teknologi informasi. Kedua, inovasi kepala sekolah dengan mengembangkan komunikasi dan jaringan kerjasama untuk saling mendukung satu sama lain untuk membentuk produktivitas dan merumuskan solusi terbaik dalam menyelesaikan persoalan-persoalan esensial organisasi sekolah. Ketiga, inovasi kepala sekolah melalui kepemimpinan yang adaptif teknologi dalam mendukung akselerasi merdeka belajar untuk mewujudkan visi dan tujuan yang baik. Ketidakpastian menuntut para pemimpin untuk beradaptasi dengan cepat terhadap situasi yang berubah dengan cepat, dan untuk memanfaatkan keterampilan dan berkonsekuensi pada jenis kepemimpinan yang diterapkan.

\section{DAFTAR PUSTAKA}

Bagwell, J. (2020). Leading Through a Pandemic: Adaptive Leadership and Purposeful Action. Journal of School Administration Research and Development, 5(S1), 30-34. https://doi.org/10.32674/jsard.v5iS1.2781

Candra, R., Rahayu, E. S., \& Putra, N. M. D. (2020). Development of Science Module SETS Approach to Strengthen Cognitive Learning Outcomes of Elementary School Students. Journal of Primary Education, 9(3), 248-257. https://doi.org/10.15294/jpe.v9i3.37713

Chandra, Situmorang, M., \& Situmeang, M. (2019). The Influence of Principal Managerial Competencies and Interpersonal Communication on Teachers Performance in Samanhudi Tanjung Pura Private Senior High School. Proceedings of the 4th Annual International Seminar on Transformative Education and Educational Leadership (AISTEEL 2019). Proceedings of the 4th Annual International Seminar on Transformative Education and Educational Leadership (AISTEEL 2019), Medan City, Indonesia. https://doi.org/10.2991/aisteel-19.2019.129

D’angelo, D., Sinopoli, A., Napoletano, A., Gianola, S., Castellini, G., del Monaco, A., Fauci, A. J., Latina, R., Iacorossi, L., Salomone, K., Coclite, D., \& Iannone, P. (2021). Strategies to exiting the COVID-19 lockdown for workplace and school: A scoping review. Safety Science, 134, 105067. https://doi.org/10.1016/j.ssci.2020.105067

Dewi, T. A. P., \& Sadjiarto, A. (2021). Pelaksanaan Pembelajaran Daring Pada Masa Pandemi Covid-19. JURNAL BASICEDU, 5(4), 1909-1917.

Djafri, N., Arwildayanto, A., \& Suking, A. (2020). Manajemen Kepemimpinan Inovatif pada Pendidikan Anak Usia Dini dalam Perspektif Merdeka Belajar Era New Normal. Jurnal Obsesi : Jurnal Pendidikan Anak Usia Dini, 5(2), 1441-1453. https://doi.org/10.31004/obsesi.v5i2.901

Fernandez, A. A., \& Shaw, G. P. (2020). Academic Leadership in a Time of Crisis: The Coronavirus and COVID-19. Journal of Leadership Studies, 14(1), 39-45. https://doi.org/10.1002/jls.21684

Gualano, M. R., Lo Moro, G., Voglino, G., Bert, F., \& Siliquini, R. (2020). Effects of Covid-19 Lockdown on Mental Health and Sleep Disturbances in Italy. International Journal of Environmental Research and Public Health, 17(13), 4779. https://doi.org/10.3390/ijerph17134779 
4252 Kepemimpinan Inovatif dalam Penyelenggaraan Pendidikan di Masa Pandemi Covid-19 - Suyitno DOI: https://doi.org/10.31004/edukatif.v3i6.1432

Harris, A., \& Jones, M. (2020). COVID 19 - school leadership in disruptive times. School Leadership \& Management, 40(4), 243-247. https://doi.org/10.1080/13632434.2020.1811479

Johannessen, J.-A., \& Skaalsvik, H. (2014). SECTION 2. Management in firms and organizations. Problems and Perspectives in Management, 12(2), 15.

Kaden, U. (2020). COVID-19 School Closure-Related Changes to the Professional Life of a K-12 Teacher. Education Sciences, 10(6), 165. https://doi.org/10.3390/educsci10060165

Kruse, S. D., Hackmann, D. G., \& Lindle, J. C. (2020). Academic Leadership During a Pandemic: Department Heads Leading With a Focus on Equity. Frontiers in Education, 5, 614641. https://doi.org/10.3389/feduc.2020.614641

Kurita, J., Sugawara, T., \& Ohkusa, Y. (2021). Estimated effectiveness of school closure and voluntary event cancellation as COVID-19 countermeasures in Japan. Journal of Infection and Chemotherapy, 27(1), 62-64. https://doi.org/10.1016/j.jiac.2020.08.012

Maladzhi, W. R., Yan, B., \& Makinde, O. D. (2012). The impact of innovative leadership on organisational culture within South African small and medium enterprises in the Western Cape, South Africa. African Journal of Business Management, 6(39), 7. https://doi.org/10.5897/AJBM12.749

Marron, J. M., \& Cunniff, D. (2014). What Is An Innovative Educational Leader? Contemporary Issues in Education Research (CIER), 7(2), 145. https://doi.org/10.19030/cier.v7i2.8485

McLeod, S., \& Dulsky, S. (2021). Resilience, Reorientation, and Reinvention: School Leadership During the Early Months of the COVID-19 Pandemic. Frontiers in Education, 6, 637075. https://doi.org/10.3389/feduc.2021.637075

Metcalf, M., \& Morelli, C. (2015). 10/9 - The Art of Leading Change: Innovative Leaders Transformation Model. 5.

Nadeak, B., \& Juwita, C. P. (2020). Kepemimpinan kepala sekolah dalam menjaga tata kelola sekolah selama masa pandemi Covid-19. Jurnal Konseling dan Pendidikan, 8(3), 207. https://doi.org/10.29210/149400

Nugroho, I., Paramita, N., Mengistie, B. T., \& Krupskyi, O. P. (2021). Higher education leadership and uncertainty during the COVID-19 pandemic. Journal of Socioeconomics and Development, 4(1), 1. https://doi.org/10.31328/jsed.v4i1.2274

Othman, A., \& Rahman, H. A. (2013). Innovative Leadership: Learning from Change Management among Malaysian Secondary School Principals. 11.

Owen, D. C., Scott, C., Adams, R., \& Parsons, D. (2015). Leadership in crisis: Developing beyond command and control. 30(3), 6 .

Setiani, A. (2020). Efektivitas Proses Belajar Aplikasi Zoom di Masa Pandemi dan Setelah Pandemi Covid19. Prosiding Seminar Nasional Pascasarjana Universitas Negeri Semarang, 8.

SKB 4 Menteri Panduan Pembelajaran Tatap Muka.pdf. (n.d.).

Somsueb, A., Sutheejariyawatana, P., \& Suwannoi, P. (2019). Indicators of Innovative Leadership for Secondary School Principals: Developing and Testing the Structural Relationship Model. International Education Studies, 12(2), 11. https://doi.org/10.5539/ies.v12n2p11

Spyropoulou, E., \& Koutroukis, T. (2021). Managing Open School Units Amid COVID-19 Pandemic through the Experiences of Greek Principals. Implications for Current and Future Policies in Public Education. Administrative Sciences, 11(3), 70. https://doi.org/10.3390/admsci11030070

Strielkowski, W., \& Wang, J. (2020). An Introduction: COVID-19 Pandemic and Academic Leadership. Proceedings of the 6th International Conference on Social, Economic, and Academic Leadership (ICSEAL-6-2019). 6th International Conference on Social, economic, and academic leadership (ICSEAL-6-2019), Prague, Czech Republic. https://doi.org/10.2991/assehr.k.200526.001 
4253 Kepemimpinan Inovatif dalam Penyelenggaraan Pendidikan di Masa Pandemi Covid-19 - Suyitno DOI: https://doi.org/10.31004/edukatif.v3i6.1432

Suheny, E., Arum, M., Wandi, D., Rahmat, A., Dasmaran, V., Adha, S., \& Purwanto, A. (2020). Develop Leadership Style Model for Indonesian SMEs Leaders During Covid-19 Pandemic. Systematic Reviews in Pharmacy, 11(8), 11.

Sutama, G. A. L. (2021). Kepemimpinan Kepala SDIT Muhammadiyah Truko Dimasa Covid-19. 7.

Suyitno. (2018). Metode Penelitian Kualitatif: Konsep, Prinsip Dan Operasionalnya (1st ed.). Akademia Pustaka- Tulungagung.

https://www.researchgate.net/publication/326957100_Metode_Penelitian_Kualitatif_Konsep_Prinsip_d an_Operasionalnya

Wilson, R. M., Bing wen, Y., \& Oluwole, D. M. (2012). The impact of innovative leadership on organisational culture within South African small and medium enterprises in the Western Cape, South Africa. African Journal of Business Management, 6(39), 10438-10444.

https://doi.org/10.5897/AJBM12.749 